\title{
Evaluation of the Synthesized Novel Iridium (III) Complexes Against HeLa Cell Lines Through In-Silico, In-Vitro and DNA Nicking
}

\author{
G. Sathya Priyadarshini ${ }^{1}$, Aathi Muthusankar ${ }^{2}$, Ramesh Subramani ${ }^{3}$, Selvi \\ Gopal ${ }^{1 *}$
}

\begin{abstract}
Globally, the pharmaceutical industry is continuously driven in search of new anticancer drugs due to increasing rate of cancer patients. Clinical trials of Cisplatin has been explored, however, usage of Cisplatin as a drug is limited due to its various side effects, hence, alternative to platinum based complex drugs and its analogues are needed. Iridium complexes have been attracted widespread interests by virtue of their pharmacological and photo-physical properties; however the less number of complexes was reported in the literature. In this article, a new series of novel Iridium (III) complexes were synthesized using substituted quinoline Schiff Base (SB) ligands and characterized by spectroscopic techniques. The in- vitro cyto-toxicity assay showed that the Iridium (III) complex activity is equal to standard Cisplatin. In addition, computational docking studies have shown that the prominent binding sites for synthesized complexes against HeLa cell lines, which is comparable with standard Cisplatin drugs and other Ruthenium complexes.
\end{abstract}

Keywords: Iridium complexes- quinoline schiff base- molecular docking- DNA nicking

Asian Pac J Cancer Prev, 22 (2), 447-455

\section{Introduction}

Transition metal based inorganic complex is playing a predominant role in the field of medicinal chemistry (Ndagi et al., 2017). The Pharmaceutical industry is constantly searching for novel anticancer drugs as urged by WHO due to the alarming rate of cancer patients (Freddie et al., 2020). It is estimated by WHO that more than 30 million people globally are in the need of anti-cancer drugs in the coming years. Clinical trials of Cisplatin (CP), platinum group of complexes were studied to treat cervical, ovarian, testicular, head and neck, breast, bladder, stomach, prostate and lung cancers (Bai et al., 2020; Mukhopadhyay et al., 2015). The usage of CP as a drug is limited due to its various side effects such as neutropenia, lymphedema, deep vein thrombosis, chemo brain, hair loss and vomiting [https://www.cdc.gov/ cancer/survivors/patients/side-effects-of-treatment]. As a result, researchers are focused on designing of novel anticancer drug that can specifically identify tumor targets to overcome the drawbacks of chemotherapeutic agents. Hence, alternative platinum based complex drugs and its analogues viz. Carboplatin, Oxaliplatin, Satraplatin,
Aroplatin, Enloplatin, Zeniplatin, Sebriplatin, Miboplatin, Picoplatin, and Iproplatin were investigated (Florea et al., 2011; Monneret, 2011; Wheate et al., 2020).

Dose related factors of platinum drugs have led to the exploration of other elements of the same series of metals. For instance, Ruthenium (Ru) and Iridium (Ir) complexes have gained significant attention for last few years due to its anticancer properties with low side effects (Sudding et al., 2014). However, Ir complexes containing NNO donors are explored to a lesser extent which can act as a better anticancer drug due to their kinetic aspects, water solubility and binding ability with DNA (Adhikari et al., 2017; Sliwinska-hill et al., 2013; Adhikari et al., 2016; Mandal et al., 2014). To make such effective anti-cancer complex drug with transition metal, ligand design is challenging to maintain its physicochemical properties such as fluorescence, photo activity and cytotoxicity. Schiff Base (SB) is being the better benign for complexation with metals as many studies were reported in the literature. SB complexes tethered with heterocyclic moieties like 4-aminoantipyrine, pyrazole, 1,2,4-triazoles, benzoxazole, triazines, and coumarins have received remarkable interest as broad-spectrum due to their wide

${ }^{1}$ Department of Chemistry, PSGR Krishnammal College for Women, Peelamedu, Coimbatore, India. ${ }^{2}$ Membrane Protein Biology Group, International Centre for Genetic Engineering and Biotechnology, New Delhi 110067, India. ${ }^{3}$ Department of Food Processing Technology \& Management, PSGR Krishnammal College for Women, Peelamedu, Coimbatore, India. *For Correspondence: selvig@psgrkcw.ac.in 
range of properties such as antibacterial, antifungal and antiviral agents (Chow et al., 2013). For example, highly hydrophobic Ir (III) complexes containing both cyclopentadienyl group and a C,N-chelating ligand have been validated their significant cytotoxic activity towards A2780 human ovarian cancer cells ( $\mathrm{Lu}$ et al., 2015). Luminescent cyclometalated Ir (III) complexes were reported for their strong selectivity for cancer cells over normal cells and as specific inhibitors for protein-protein inhibition (Śliwińska-Hill et al., 2013; Xu et al., 2020).

The main reason for choosing the Iridium is due to the inertness of Iridium complexes with $5 \mathrm{~d}^{6}$ low spin configuration which inhibits the kinase enzymes (significant in angiogenesis in tumor progression). In this article, a series of new Iridium (III) complexes bearing a salicylidene hydrazino and thiosemicarbazino ligand and different types of substituent in quinoline $\left(\mathrm{N}^{\wedge} \mathrm{N}\right)$ ancillary ligands were synthesized and characterized. The experiment results from in vitro cytotoxicity assay and molecular docking shows that the Iridium (III) complex activity is equal to standard Cisplatin which is also supported by computational docking studies.

\section{Experimental}

\section{Materials and Methods}

The analar grade of salicyaldehyde, hydrazinehydrate, distilled ethanol, thiosemicarbazide, Iridium (III) chloride trihydrate and solvents were purchased from Merck. Thin layer chromatography (TLC) was performed using TLC plates coated with silica gel. Petroleum ether and ethyl acetate was used as eluant on TLC. Spots were identified using iodine. The column chromatography technique was used to purify the crude sample using silica gel as adsorbent. IR spectra were recorded in Schimadzu (ATIR) and the absorption frequencies quoted in reciprocal centimeters. ${ }^{1} \mathrm{H}-\mathrm{NMR}$ spectra were recorded in a $400 \mathrm{MHz}$ NMR Spectrometer. TGA-DSC curves were recorded on Shimadzu $60 \mathrm{H}$ model at $10^{\circ} \mathrm{C} / \mathrm{min}$. heating rate. Powder $\mathrm{X}$ ray diffraction pattern were recorded using Bruker diffractometer model D8.

General Procedure for the preparation of ligands $H L_{1}-H L_{4}$

The ligands $\left(\mathrm{HL}_{1}-\mathrm{HL}_{4}\right)$ were obtained by the following steps. First step was refluxing the 2-chlorosubstituted quinoline in ethanol and hydrazine hydrate (for $\mathrm{HL}_{1}$ and $\mathrm{HL}_{2}$ ) and thiosemicarbazide (for $\mathrm{HL}_{3}$ and $\mathrm{HL}_{4}$ ) in ethanol for $24 \mathrm{~h}$ at $80^{\circ} \mathrm{C}$. The corresponding hydrazones and thiosemicarbazones products obtained were dissolved in ethanol and added slowly to the magnetically stirred solution of salicyaldehyde. In the second step, the reaction mixture was stirred for $6 \mathrm{~h}$ and the completion of the reaction was checked by TLC. The resulting solution was concentrated to half of its volume. The product regenerated from the solution was washed with petroleum ether and it was recrystallized from ethanol (Figure 1a and 1b).
General Procedure for the preparation of Iridium (III) Complexes $1 a, 1 b, 2 a$ and $2 b$

A hot ethanolic solution of respective ligands was added slowly to ethanolic solution of $\mathrm{IrCl}_{3} .3 \mathrm{H}_{2} \mathrm{O}(0.1 \mathrm{~g}$, $0.3355 \mathrm{mM}$ ) with continuous shaking and the colour changed from yellowish green to intense colour during addition. The resulting solution was refluxed for about $6 \mathrm{~h}$ and the solid mass was precipitated and filtered/washed by petroleum ether. It was then recrystallized with a mixture of chloroform and ethanol (Figure 1c and 1d).

\section{DNA nicking assay}

$2 \mu \mathrm{L}$ of the Ir complexes were added to $5 \mu \mathrm{L}$ of plasmid DNA (PBR322) along with $2 \mu \mathrm{L}$ of hydrogen peroxide and incubated for 1 hour at $37^{\circ} \mathrm{C}$. The resulting sample was loaded in $1.2 \%$ agarose gel electrophoresis and results were recorded by using a UV transilluminator.

\section{Cytotoxicity studies}

The anticancer activity of the synthesized compounds was carried out against HeLa cancer cell line by MTT assay method. The cell line was cultured and preserved in DMEM medium along with antibiotics in a T-shaped flask kept under incubator chamber at $37.5^{\circ} \mathrm{C}$ with $5 \%$ $\mathrm{CO}_{2}$ for 24-72 hrs. Samples and control were prepared in different concentrations $(1 \mathrm{mg} / 1 \mathrm{~mL})$, after mixing well in the cell cultural plate, cells were kept for $24 \mathrm{hrs}$ in $5 \% \mathrm{CO}_{2}$ incubator. After incubation, cells were washed with trypsin and added MTT dye in the cell cultured plate. These plates were again incubated for $24 \mathrm{hrs}$ in $5 \% \mathrm{CO}_{2}$ atmosphere. Thereafter the optical density value was monitored from ELISA reader at $570 \mathrm{~nm} . \%$ of cell death $=($ Control OD -Sample OD)/Control OD x 100.

\section{Molecular Docking}

Human epidermal growth factor receptor was downloaded from Protein Data Bank (PDB) with the following PDB ID: 2ITY. Docking analysis was performed by Autodock 4.0 tool. 3D structure of protein and ligand were prepared for docking analysis with MGL Tool 1.5.6. Grid box was prepared as $\mathrm{X}=56, \mathrm{Y}=68, \mathrm{Z}=54$ with gridpoint spacing angstrom of $0.858 \AA$. The $\mathrm{X}, \mathrm{Y}, \mathrm{Z}$ coordinates were specified for grid point value of $\mathrm{X}=-58.166, \mathrm{Y}=$ $-5.006, Z=-21.212$ and total grid points per map of 216315 were constructed enveloping the human epidermal growth factor receptor. The given input parameters were analyzed using a genetic algorithm and set 100 runs for each docking process. Finally, the best conformation was selected with the lowest binding energy, ligand efficiency, with more number of hydrogen bonds.

\section{Results}

\section{Ligands and Ir (III) Complexes}

A schematic diagram of synthesized ligands $\left(\mathrm{HL}_{1}-\mathrm{HL}_{4}\right)$ and complexes (1a, 1b, 2a and $2 \mathrm{~b}$ ) is given in the Figure 1. All the ligands are soluble in common organic solvents (ethanol, chloroform, methanol and acetone). The metal complexes are partially soluble in common organic solvents and completely soluble in DMSO and DMF All the synthesized complexes were found to be stable in air 
and light. Molar conductivity measurements envisage the nature of the molecule to be electrolytic or nonelectrolytic. The study of electrolytic behaviour using conductivity bridge (Equiptronics Conductivity Meter Model No-E660) of metal complex 1a, 1b, 2a and 2b in solutions (DMF) provides brief insight on the nature and composition. The measured molar conductance of the
Evaluation of the Synthesized Novel Iridium (III) Ccomplexes metal complexes $1 \mathrm{a}, 1 \mathrm{~b}, 2 \mathrm{a}$ and $2 \mathrm{~b}$ were found to be in the range of $25-53 \Omega^{-1} \mathrm{~cm}^{2} \mathrm{~mol}^{-1}$. It was evidenced that if conductance in DMF medium is less than $60 \Omega^{-1} \mathrm{~cm}^{2} \mathrm{~mol}^{-1}$, substance is non-electrolyte in nature and if it conductance is greater than $60 \Omega^{-1} \mathrm{~cm}^{2} \mathrm{~mol}^{-1}$, substance is electrolyte in nature. The values obtained for the complexes $1 \mathrm{a}, 1 \mathrm{~b}, 2 \mathrm{a}$ and $2 \mathrm{~b}$ in our study indicates that synthesized complexes

Table 1. IR Data of Ligands and Complexes in $\mathrm{cm}^{-1}$

\begin{tabular}{lcccccc}
\hline Compound & $v(\mathrm{O}-\mathrm{H})$ & $v(\mathrm{~N}-\mathrm{H})$ & $v(\mathrm{C}=\mathrm{N})$ & $v(\mathrm{C}-\mathrm{O})$ & $v(\mathrm{~N}-\mathrm{H})$ & $v(\mathrm{C}=\mathrm{S})$ \\
\hline $\mathrm{HL}_{1}$ & 3289 & 3050 & 1608 & 1253 & - & - \\
$\mathrm{HL}_{2}$ & 3129 & 3030 & 1600 & 1270 & - & - \\
$\mathrm{HL}_{3}$ & 3320 & 3126 & 1590 & 1271 & 2950 & 1362 \\
$\mathrm{HL}_{4}$ & 3317 & 3263 & 1592 & 1270 & 3170 & 1366 \\
$1 \mathrm{a}$ & 3386 & 3089 & 1565 & 1110 & - & - \\
$1 \mathrm{~b}$ & 3380 & 3150 & 1574 & 1095 & - & - \\
$2 \mathrm{a}$ & 3350 & 3100 & 1575 & 1048 & 2998 & 1398 \\
$2 \mathrm{~b}$ & 3381 & 2979 & 1589 & 1066 & 2926 & 1390 \\
\hline
\end{tabular}
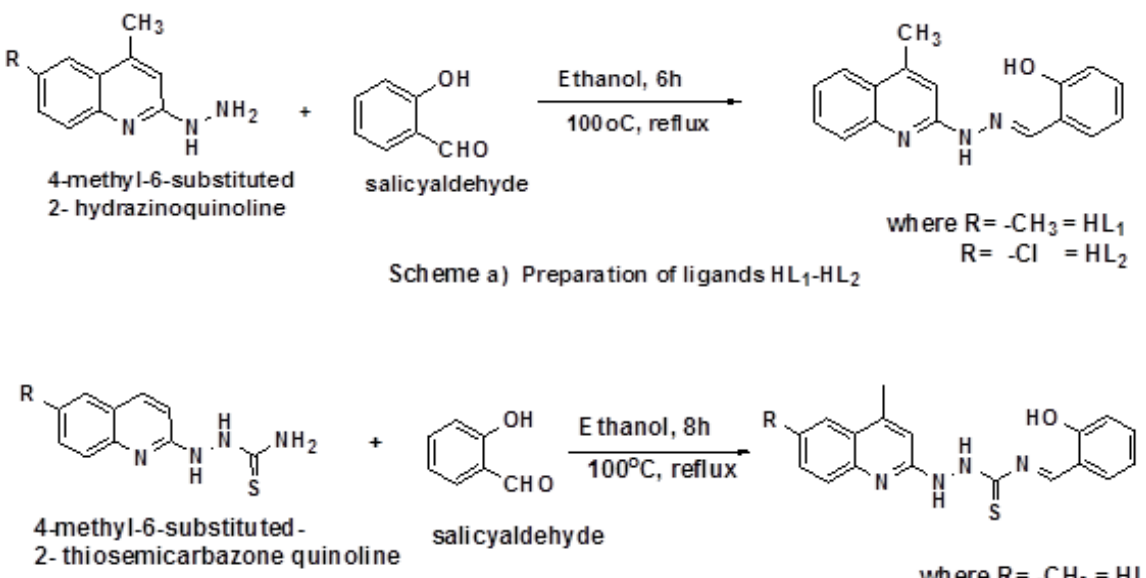

$$
\text { 2- thiosemicarbazone quinoline Salicyaldehyde } \quad \text { where } R=-\mathrm{CH}_{3}=\mathrm{HL}_{3}
$$

Scheme b) Preparation of ligands $\mathrm{HL}_{3}-\mathrm{HL}_{4}$

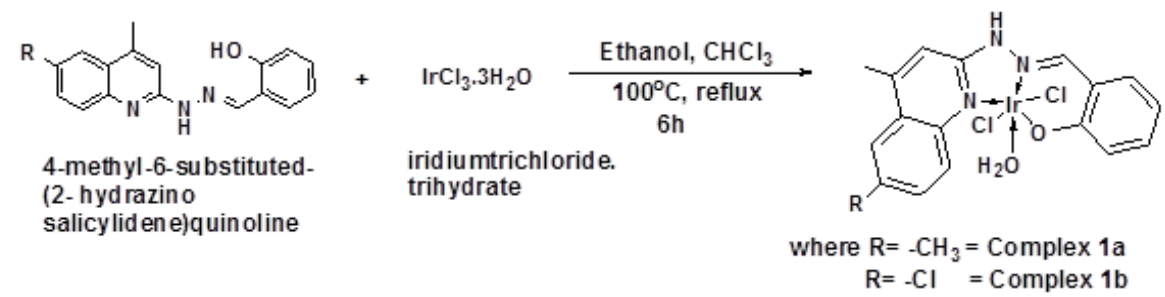

Scheme c) Preparation of Complex 1a and 1b

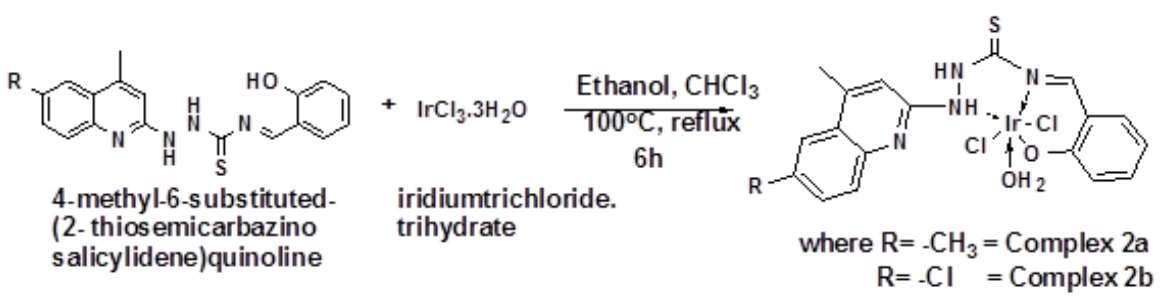

Scheme d) Preparation of Complex 2a and 2b

Figure 1. Schematic Diagram of Prepared Ir (III) Complexes: a. Preparation of ligands $\mathrm{HL}_{2}-\mathrm{HL}_{2}$; $b$. Preparation of ligands $\mathrm{HL}_{3}-\mathrm{HL}_{4}$; c. Preparation of complex $1 \mathrm{a}$ and $1 \mathrm{~b}$; d. Preparation of complex $2 \mathrm{a}$ and $2 \mathrm{~b}$. 

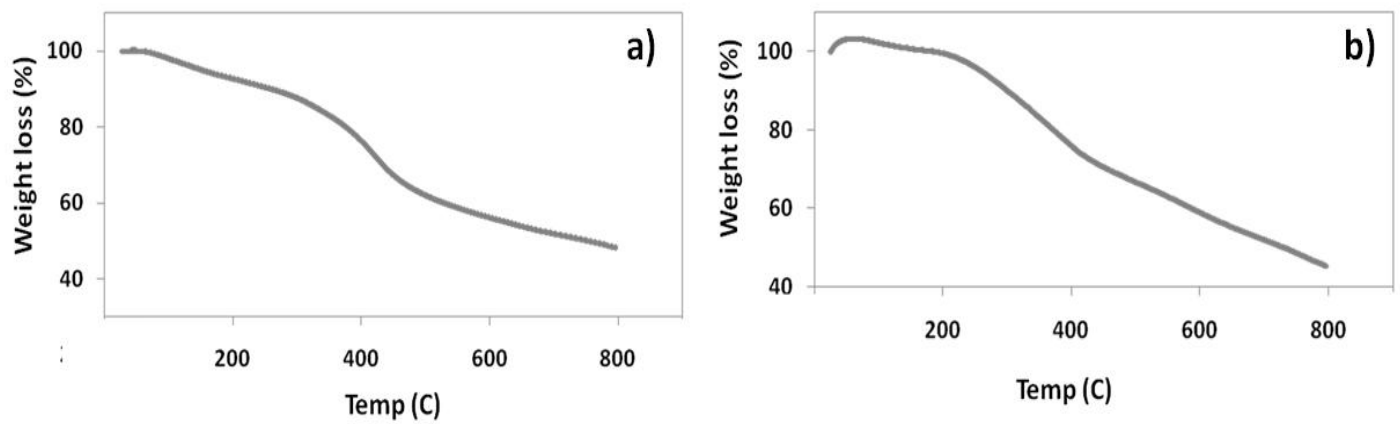

Figure 2. a) TGA Curve of Iridium Complex 1a, b) TGA Curve of Iridium Complex 2a.

Table 2. ${ }^{1} \mathrm{H}$ - NMR Data of Ligands and Complexes (in ppm)

\begin{tabular}{|c|c|c|c|c|c|c|}
\hline Compound & $\delta(\mathrm{O}-\mathrm{H})$ & $\delta(\mathrm{N}-\mathrm{H})$ & $\delta(\mathrm{N}-\mathrm{H})$ & $\delta($ aromatic $\& \mathrm{HC}=\mathrm{N})$ & $\delta\left(\mathrm{CH}_{3}\right)$ & $\delta\left(\mathrm{CH}_{3}\right)$ \\
\hline $\mathrm{HL}_{1}$ & 9 & 11.2 & - & $7.8-7.0$ & 3.3 & 2.4 \\
\hline $\mathrm{HL}_{2}$ & 8.8 & 11.3 & - & $7.5-6.8$ & & 1.4 \\
\hline $\mathrm{HL}_{3}$ & 9.7 & 11.4 & 10.3 & $8.3-6.9$ & 3.3 & 2.3 \\
\hline $\mathrm{HL}_{4}$ & 9 & 11.3 & 10.8 & $7.8-6.8$ & & 2.3 \\
\hline $1 \mathrm{a}$ & 5.3 & 11.2 & - & 7.8-7.0 & 3.4 & 2.4 \\
\hline $1 b$ & 5.8 & 11.3 & - & $7.5-6.8$ & & 1.5 \\
\hline $2 \mathrm{a}$ & 6.1 & 11.4 & 9.8 & $8.0-6.8$ & 3.3 & 2.4 \\
\hline $2 b$ & 6.3 & 11 & 9 & 7.9-6.8 & & 2.5 \\
\hline
\end{tabular}

are non-electrolytic in nature. (Ali et al., 2013; Wang et al., 2018).

\section{Spectroscopic studies}

The coordination behaviors of ligands were determined by comparing the vibrational frequency of the ligands and their metal complexes (Abd-Elzaher et al., 2016; Kumar et al., 2016; KantiSeth et al., 2015). The IR spectrum of the ligands $\left(\mathrm{HL}_{1}-\mathrm{HL}_{4}\right)$ showed characteristic stretching frequency for $-\mathrm{OH},-\mathrm{NH},-\mathrm{C}=\mathrm{N}$ and $\mathrm{C}-\mathrm{O}$ groups as shown in the (Table 1) [IR Spectra Figures S1-S8 are given as supplementary information]. The $-\mathrm{OH},-\mathrm{NH}$ and $-\mathrm{C}-\mathrm{O}$ groups of the ligands $\left(\mathrm{HL}_{1}-\mathrm{HL}_{4}\right)$ showed a stretching frequency in the range of $3317-3129 \mathrm{~cm}^{-1}, 3,263-2,950$ $\mathrm{cm}^{-1}$ and $1,271-1,253 \mathrm{~cm}^{-1}$. The peak at the range of 1608 $1590 \mathrm{~cm}^{-1}$ of the ligands is attributed to azomethine group.

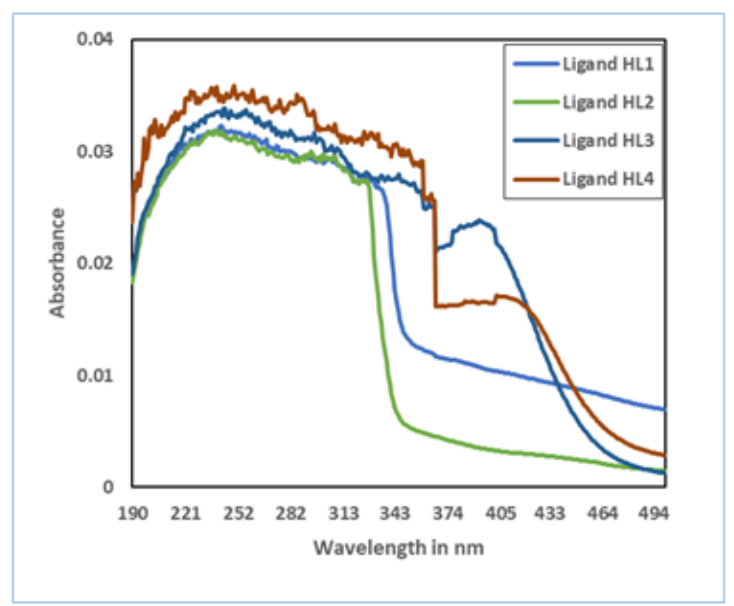

The $\mathrm{C}=\mathrm{S}$ group for the ligands $\left(\mathrm{HL}_{3}\right.$ and $\left.\mathrm{HL}_{4}\right)$ resonates at 1,362 and $1,365 \mathrm{~cm}^{-1}$. The IR spectrum of the metal complexes (1a, 1b, 2a and 2b) exhibits broad peaks in the region of 3,386-3,350 $\mathrm{cm}^{-1}$ indicating the presence of coordinated water molecules. Disappearance of sharp signal of $-\mathrm{OH}$ of the ligands and shift in the stretching frequency of C-O group in the metal complexes infers that the ligands are coordinated through the phenolic oxygen of the salicylaldehyde ring. The strong absorption of complex $1 \mathrm{a}, v \mathrm{C}=\mathrm{N}$ at $1,565 \mathrm{~cm}^{-1}$ and $v \mathrm{~N}-\mathrm{H}$ at $3089 \mathrm{~cm}^{-1}$ compared to that of the ligand HL1 reduced to lower wave numbers suggested the coordination to the metal occurs through the $-\mathrm{NH}$ and azomethine groups. The retaining of the peak of $v \mathrm{C}=\mathrm{S}$ group in the metal complex $2 \mathrm{a}$ and $2 \mathrm{~b}$ indicates that they are not participated in bonding. In conclusion, these data revealed that the ligands are

Figure 3. Absorption Spectra of Ligands (a) and metal complexes 1a, 1b, 2a and $2 \mathrm{~b}$ in DMSO medium of $10^{-5}$ concentrations (b)

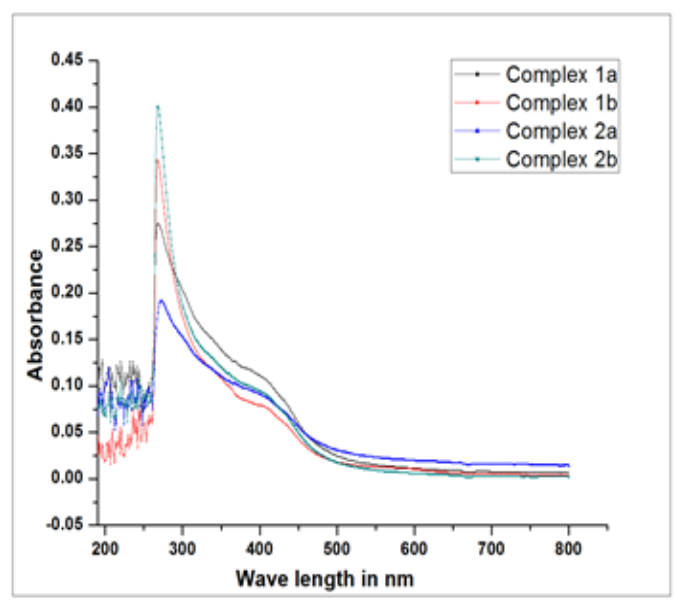



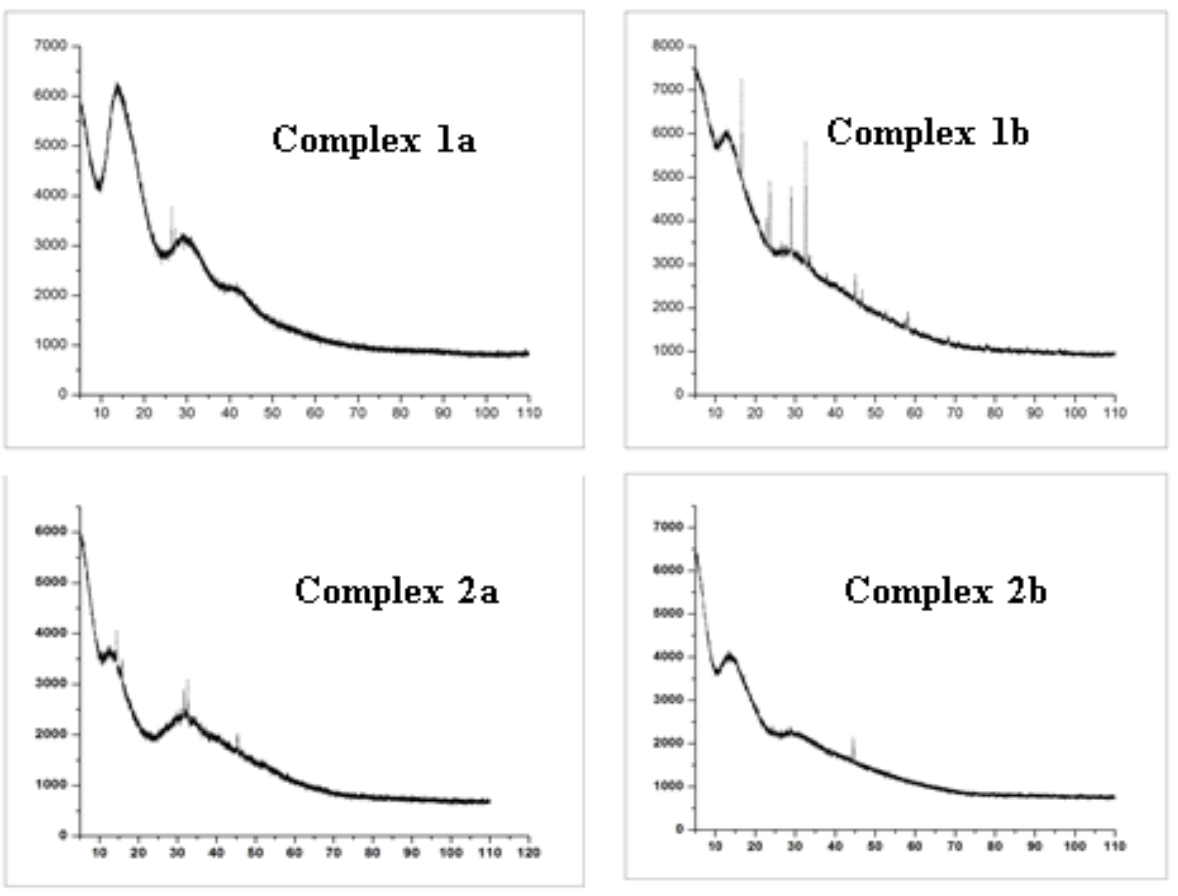

Figure 4. X Ray Diffractogram of Iridium Complex 1a, 1b, 2a \& 2b

coordinated with NNO donor fashion to the metal.

The ${ }^{1} \mathrm{H}$ NMR spectrum (Kanti Seth et al., 2017; Hasan et al., 2015; Sinha et al., 2015; Abu Shamma Hijazi et al., 2018) of the ligands $\left(\mathrm{HL}_{1}-\mathrm{HL}_{4}\right)$ resonates at $6.5-7.9 \mathrm{ppm}$ assigned to aromatic protons as shown in the (Table 2) ( ${ }^{1} \mathrm{H}-\mathrm{NMR}$ spectra Figures S9-S16 are given as supplementary information). The 4-methyl protons of the ligands viewed at $1.4-2.5$ ppm appeared as singlet. The Peak at 11.0-11.4 ppm and 8.8-9.7 ppm was attributed to the $-\mathrm{NH}$ and $-\mathrm{OH}$ groups. The $-\mathrm{NH}$ group of thiosemicarbazino ligand $\left(\mathrm{HL}_{3}\right.$ and $\left.\mathrm{HL}_{4}\right)$ resonantes at 10.3 and $10.8 \mathrm{ppm}$. The proton NMR spectral values (Table 2) of the metal complexes $1 \mathrm{a}, 1 \mathrm{~b}, 2 \mathrm{a}$ and $2 \mathrm{~b}$, methyl protons signal appeared around 1.2-2.8 $\mathrm{ppm}$. The disappearance of phenolic - $\mathrm{OH}$ peak at 8.8-9.7 ppm and appearance of signals at 5.3-6.3 ppm indicates that the presence of coordinated water molecules. The peak at $\delta 10.3$ and $10.8 \mathrm{ppm}$ corresponds to $\mathrm{NH}$ of the ligands $\left(\mathrm{HL}_{3}\right.$ and $\mathrm{HL}_{4}$ ) shifted to $\delta 9.8$ and $9.0 \mathrm{ppm}$ indicates the ' $\mathrm{NH}$ ' is coordinated to metal. Hence the ' $\delta$ ' value shifted from $\delta 10.3$ to 9.8 and 10.8 to 9.0 compared to ligand, confirmed the mode of coordination of ligand to metal. From the spectral values it is confirmed that the ligand is coordinated through $\mathrm{C}-\mathrm{O},-\mathrm{NH}$ and $-\mathrm{CH}=\mathrm{N}$ to the metal.

\section{Thermal Analysis}

Thermo Gravimetric Analysis (TGA) was used to analyze the presence of water molecules outside the

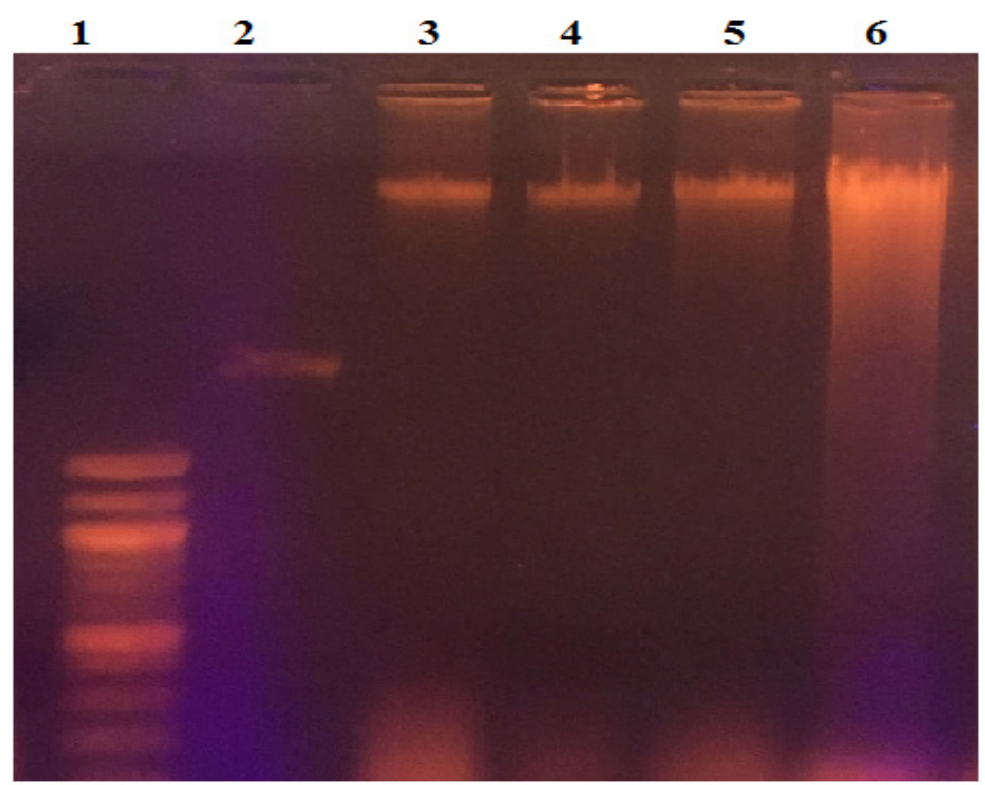

Figure 5. DNA Cleavage of Various Lanes of Metal Complexes - Lane 1, Marker (1kb Ladder); Lane 2, Control DNA; Lane 3, Complex 1a+ DNA; Lane 4, Complex 1b+ DNA; Lane 5, Complex 2b+ DNA; Lane 6, Complex 2a+ DNA 


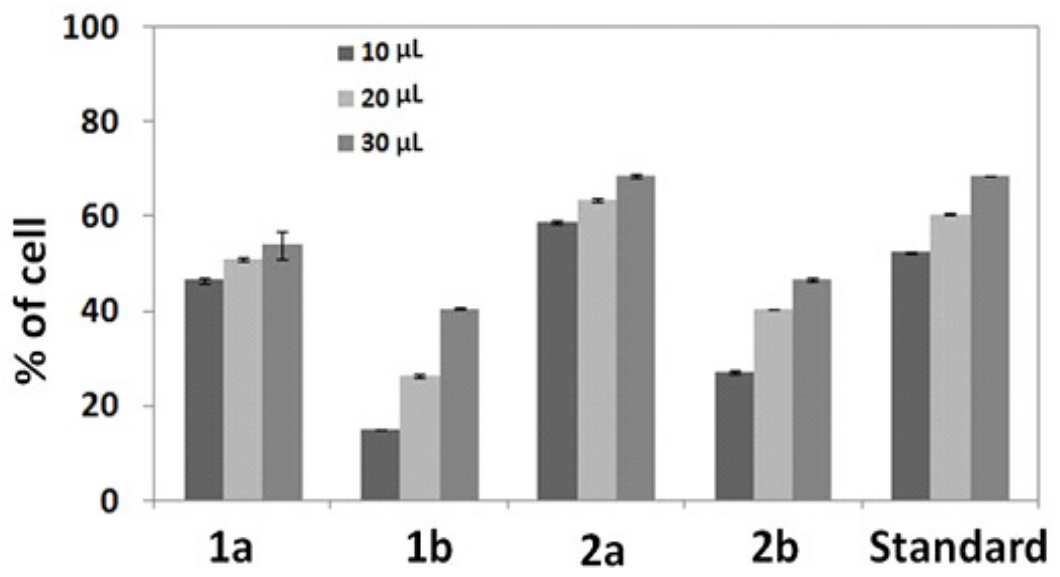

Figure 6. Percentage Cell Death of Metal Complexes 1a, 1b, 2a and 2b

coordination sphere in the metal complexes, decomposition temperature and stability of the complexes(Yang et al., 2015). TGA for the complexes were analyzed (heating rate increment is $20^{\circ} \mathrm{C} \mathrm{min}{ }^{-1}$ ) under nitrogen atmosphere. Weight loss was measured from ambient temperature upto $800^{\circ} \mathrm{C}$. The TGA curve of the metal complex 1a showed different phase decomposition as shown in the Figure $2 \mathrm{a}$. The initial decomposition was observed at a temperature $308^{\circ} \mathrm{C}(17 \%)$. The calculated weight loss in percentage implies the loss of one coordinated water molecule and two chlorine atoms. The second phase decomposition observed in a temperature value of $476.1^{\circ} \mathrm{C}$. Weight loss in percentage with a range of $(40 \%)$ indicates the ligand decomposition and leaving the metal residue as iridium oxide. The TGA curve of metal complex 2 a showed decomposition in three steps as shown in the Figure $2 \mathrm{~b}$. The first stage decomposition at a range $200^{\circ} \mathrm{C}(3 \%)$ measures the loss of one coordinated water molecule. The second stage decomposition was obtained with the gradual decrease in the temperature range of $305^{\circ} \mathrm{C}$. The weight loss in percentage at the range of $(12 \%)$ is corresponding to the cleavage of two chlorine atoms and after that gradual decrease at $700{ }^{\circ} \mathrm{C}$ leaves the metal residue as iridium oxide similar to complex $1 \mathrm{a}$. Complex $1 \mathrm{~b}$ and $2 \mathrm{~b}$ has also showed the loss of one coordinated water molecule and two chlorine atoms similar with 1 a \& 2 a complexes (data not shown).

UV - Visible absorption spectroscopy

The absorption spectra of the Ir (III) complexes 1a, 1b, 2a and 2b Figure 3. shows Metal-to-Ligand-Charge Transfer (MLCT) where an electron is promoted from a metal $\mathrm{d}$ orbital to a vacant $\pi^{*}$ orbital of the ligand (along with Ligand-Centered (LC) $\pi-\pi^{*}$ transitions). The synthesised compounds $\mathrm{HL}_{1}-\mathrm{HL}_{4}$ showed that three absorption bands for the ligands at 221-261, 282-313 and 375-403 $\mathrm{nm}$ (Figure 3a). The band from 221-261nm is assigned to $\pi-\pi^{*}$ transition of the aromatic rings, absorption at $282-313 \mathrm{~nm}$ is due to- $\mathrm{n}-\pi^{*}$ transition -of $\mathrm{C}=\mathrm{N}$ group. Charge transfer transition is assigned for the band at 375-403 nm (Zhou et al., 2017). The metal complexes $1 \mathrm{a}, 1 \mathrm{~b}, 2 \mathrm{a}$ and $2 \mathrm{~b}$ exhibited absorption bands at 325-329 $\mathrm{nm}$ ascribed to ${ }^{1}$ LLCT transitions as shown in the Figure $3 \mathrm{a}$. In addition, band at $408-425 \mathrm{~nm}$ is contribution of spin allowed ${ }^{1}$ MLCT and ${ }^{1} \mathrm{LC}$ transitions and low intense band above $450 \mathrm{~nm}$ is due to spin forbidden singlet to triplet metal to ligand charge transfer and the strong spin orbit coupling effects of iridium atom of the complexes.

\section{Powder XRD}

Powder X-ray diffraction measurement (XRD) considered as an alternative tool to get information about the geometric and inter atomic arrangements of the molecules. The crystal lattice parameters of the complexes of iridium complexes 1a and $2 \mathrm{a}$ were measured on Bruker D8 XRD advanced diffractometer in the range $5^{\circ}$ to $110^{\circ}$ of 2 theta value Figure 4 . The three $2 \theta$ peaks are corresponds to (111), (200) and (220) planes and the lattice parameters were calculated (Paula et al., 2013; Boultif et al., 2004). The lattice parameter of the complex 1a were found to be

Table 3. Interaction of Synthetic Compounds with Human Epidermal Growth Factor Receptor

\begin{tabular}{lcccc}
\hline Compounds & $\begin{array}{c}\text { Binding energy } \\
(\mathrm{Kcal} / \mathrm{mol})\end{array}$ & $\begin{array}{c}\text { Ligand efficiency } \\
(\mathrm{Kcal} / \mathrm{mol})\end{array}$ & $\begin{array}{c}\text { Hydrogen bond interaction residues } \\
\text { with atoms }\end{array}$ & $\begin{array}{c}\text { Distance between residues } \\
\left(\mathrm{A}^{\circ}\right)\end{array}$ \\
\hline $\mathrm{HL}_{1}$ & -5.26 & -0.24 & GLY863:H:O; & 2.6 \\
$\mathrm{HL}_{3}$ & -5.5 & -0.22 & ALA864:O:H & 2.1 \\
& & & GLU868:OE1:HN; & 2.7 \\
Complex 1a & -6.17 & -0.21 & ARG889:O:H & 2.4 \\
Complex 2a & -7.04 & -0.23 & GLU866:OE1:H & 2.2 \\
& & & GLY857:O:H; & 2.5 \\
\hline
\end{tabular}



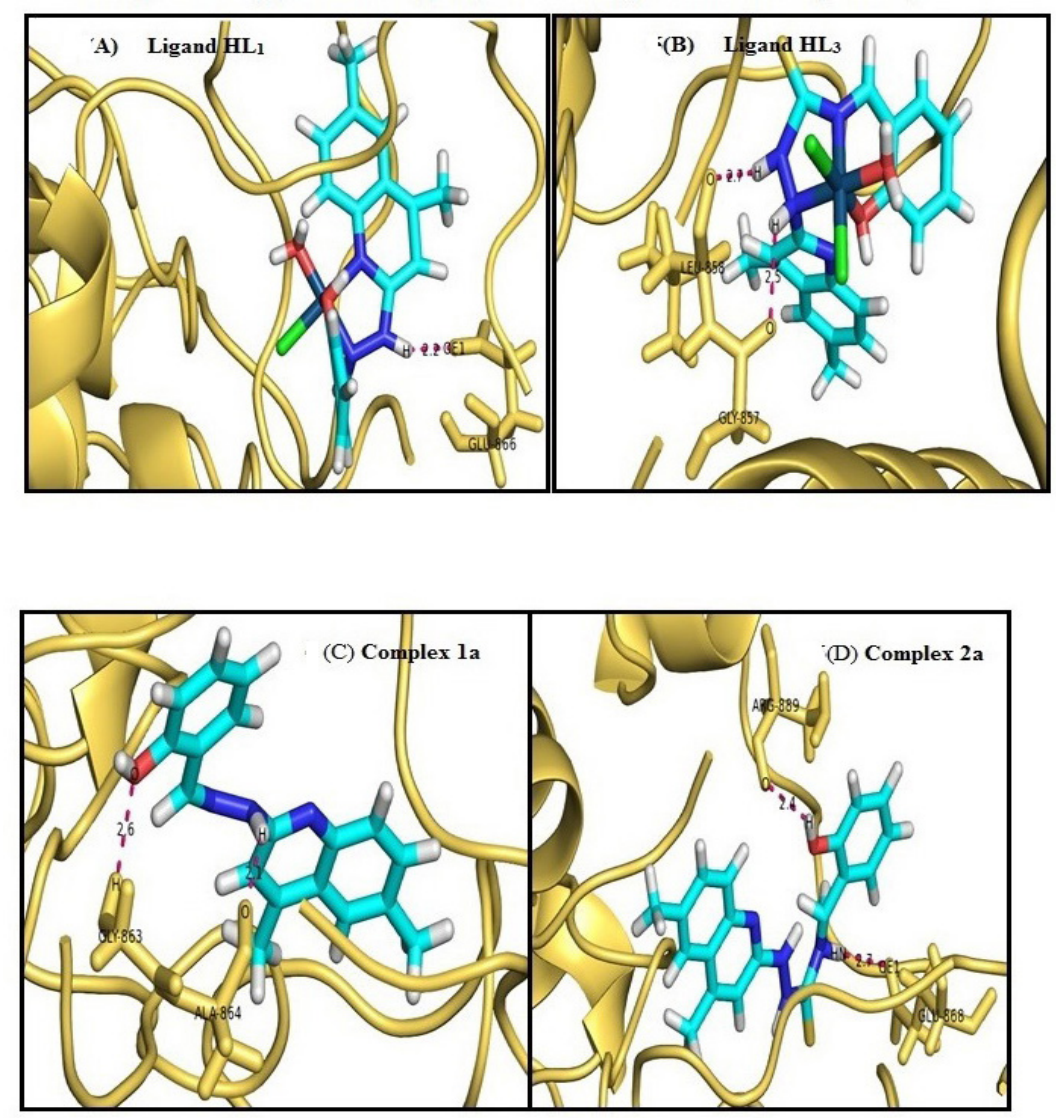

Figure 7. Human Epidermal Growth Factor Receptor Interacted with Ligand are Represent by Yellow Orange, Cyan and Magenta Colors Respectively. Docking pose of A) ligand $\mathrm{HL}_{1}$ B) ligand $\mathrm{HL}_{3} \mathrm{C}$ ) Complex 1a D) Complex 2a

$a=7.915, b=18.4558, c=14.2421, \alpha=90.000, \beta=95.025, \gamma$ $=90.00$ and the data revealed that the complex 1a belongs to the monoclinic crystal. The lattice parameter of the complex $2 \mathrm{a}$ were found to be $\mathrm{a}=7.9010, \mathrm{~b}=18.4655$, $c=14.3158, \alpha=90.000, \beta=84.959, \gamma=90.00$ and it also possess monoclinic crystal system. Similarly, the lattice parameter of the complex $1 \mathrm{~b}$ and $2 \mathrm{~b}$ were also indicated that the synthesized complexes are monoclinic crystal system.

\section{DNA Cleavage study}

Investigations on interaction of DNA with small molecules are basic in the design of new drug in the field of pharmaceutical chemistry. Some metal complexes interact with DNA and induce the breakage of DNA strands. Thus to cancer genes, after DNA strand cleaves, the DNA double strands break, the replication ability of the cancer gene is destroyed (Soundararajan et al., 2017; Ganapathy et al., 2017; Aduri et al., 2017; SurendraBabu et al., 2017; Kavitha et al., 2016). To access the DNA cleavage ability of the metal complexes $1 \mathrm{a}, 1 \mathrm{~b}, 2 \mathrm{a}$ and 2b (Figure 5) supercoiled plasmid DNA (PBR322) along with hydrogen peroxide was incubated DNA for 1 hour at $37^{\circ} \mathrm{C}$. Incubated samples were loaded into agarose gel electrophoresis. To the $1.2 \%$ Agarose gel, along with DNA ladder (Biolab) all the samples were loaded separately with $50 \mathrm{~V}$ to examine the DNA cleavage. The study revealed that the compounds has cleaved the DNA and produced the smeared DNA while running on 1.2\% agarose gel.

\section{Cytotoxicity Studies}

Cellular level in vitro cytotoxicity study was carried out against HeLa cancer cell line for four of the metal complexes (1a, 1b, 2a and 2b) compared with the standard drug Cisplatin (Mandal et al., 2014; Yun et al., 2007). The stock solutions of the samples were prepared with the concentration of $1 \mathrm{mg} / \mathrm{lmL}$ and distributed in the cells as $10 \mu \mathrm{L}, 20 \mu \mathrm{L}$ and $30 \mu \mathrm{L}$. The comparative analysis of cytotoxic activity of compounds with Cisplatin was conducted in order to better understand their pharmacological behavior. The two leaving $-\mathrm{Cl}$ groups in Cisplatin are responsible for their pharmacokinetics, as same in the case of our compounds. The electronic effect on the metal coordinated ligand might influence the strength of $\mathrm{M}-\mathrm{C}, \mathrm{M}-\mathrm{O}$ and $\mathrm{M}-\mathrm{N}$ bond as well as the rate of hydrolysis which in turn affects the anticancer activity of the complex as mentioned. The compounds (1a, 1b, 2a and $2 b$ ) were analyzed, the structure of metal complexes having the chelated system (i-e) NNO fashion, which stabilize the compounds. The two $-\mathrm{Cl}$ groups present in the compounds leads to fast reduction and high toxicity. On comparing with the standard, the compounds 1a and $2 \mathrm{a}$ were more cytotoxic towards the cell lines than $1 \mathrm{~b}$ and $2 \mathrm{~b}$ as shown in the Figure 6.

\section{Molecular Docking}

Molecular docking analysis of human epidermal growth factor receptor (PDB ID: 2ITY) interacted with synthetic compounds Table 3 (ligand $\left(\mathrm{HL}_{1}\right.$ and $\left.\mathrm{HL}_{3}\right)$ and metal complex 1a and 2a) (Morris et al., 2009; Mohammed 
et al., 2017; Yin et al., 2010; Ang et al., 2011]. From these analysis Figure $7 \mathrm{~A}, \mathrm{HL}_{1}$ atomic interaction between hydrogen, oxygen atoms of GLY863, ALA864 (-5.26Kcal/ mol) and oxygen, hydrogen atoms of HL1 compound and Figure 7B, HL3 shown atomic interaction between OE1, oxygen atoms of GLU868, ARG889 $(-5.5 \mathrm{Kcal} / \mathrm{mol})$ and $\mathrm{HN}$, oxygen atoms of $\mathrm{HL}_{3}$ compound. Complex 1a shows atomic interaction between OE1 atom of GLU866 $(-6.17 \mathrm{Kcal} / \mathrm{mol})$ and hydrogen atom of 1 a compound and complex 2 a shows atomic interaction between oxygen's atoms of GLY857, LEU858 (-7.04 Kcal/mol) and hydrogen's atoms of 2 a compound in Figures $7 \mathrm{C}$ and 7D. From the results obtained the binding energy of the synthetic compounds are in the order Complex $2 \mathrm{a}<$ Complex 1a $<\mathrm{HL}_{3}<\mathrm{HL}_{1}$ and their bond length between the binding sites falls within the limited range for all the synthetic compounds $\left(3 \mathrm{~A}^{\circ}\right)$ in Table 3 and also the results inferred that apart from the $\mathrm{H}-\mathrm{O}$ (amino acid- $\mathrm{HL}_{1}$, $\mathrm{HL}_{3}$, Complex 1a and 2a), O-H (amino acid- $\mathrm{HL}_{1}, \mathrm{HL}_{3}$, Complex 1a and 2a), O-NH- (aminoacid- $\mathrm{HL}_{3}$ ) are the prominent site of binding between the enzyme and the suspected drug in comparison with Complex $1 \mathrm{~b}$ and $2 \mathrm{~b}$.

In conclusion, a series of novel four iridium (III) complexes (1a, 1b, 2a and 2b) of 4,6-dimethyl-2(salicylidenehydrazino)quinoline $\mathrm{HL}_{1}$, 4-methyl-6-chloro2-(salicylidene hydrazino) quinoline $\mathrm{HL}_{2}, 4,6$-dimethyl2-(salicylidenethiosemicarbazino)quinoline $\mathrm{HL}_{3}$ and 4-methyl-6-chloro-2-(salicylidenethiosemicarbazino) quinoline $\mathrm{HL}_{4}$ were synthesised. All the synthesised ligands and complexes were well characterized by spectral and thermal analysis. The complexes were found to exhibit octahedral geometry with monoclinic crystal lattice. DNA cleavage studies were analysed using plasmid DNA (PBR322) along with hydrogen peroxide by agarose gel electrophoresis. The studies explained that the complexes have the ability to cleave the supercoiled DNA. The in vitro cytotoxicity studies was investigated against HeLa Cancer Cell Line by MTT assay and the findings are the complex 1a and $2 \mathrm{a}$ showed better cytotoxicity almost equal to standard drug Cisplatin. Further the complexes were docked with human epidermal growth factor receptor and found to be a good interaction with compounds.

\section{Acknowledgements}

The authors duly acknowledge the partial financial support from GRG- TRUST.

\section{References}

Abd-Elzaher MM, Labib AA, Mousa HA, et al (2016). Synthesis, anticancer activity and molecular docking study of Schiff base complexes containing thiazole moiety. J Basic Appl Sci, 5, 85-96.

Abu S, Hijazi A, Ali Shayma, et al (2018). Synthesis, characterization and biological properties of mixed ligand complexes of cobalt(II/III) valproate with 2,9-dimethyl-1,10phenanthroline and 1,10-phenanthroline. Appl Organometal Chem, 32, 1-12.

Adhikari S, Sutradhar D, Shepherd SL, et al (2016). Synthesis, structural, DFT calculations and biological studies of rhodium and iridium complexes containing azine Schiff-base ligands. Polyhedron, 117, 404-14.
Adhikari S, Hussain O, Phillips R, et al (2018). Half-sandwich d6 metal complexes comprising of 2-substituted-1,8napthyridine ligands with unexpected bonding modes: Synthesis, structural and anti-cancer studies. J Organomet Chem, 854, 27-37.

Aduri S, VenkataRamana Reddy CH, Sireesha B, et al (2017). Synthesis, characterization, DNA binding, DNA cleavage and antibacterial studies of $\mathrm{Ni}$ (II) and $\mathrm{Cu}$ (II) complexes of pyridoxal semicarbazone. Der Pharma Chem, 9, 90-8.

Ali I, Wani WA, Saleem K, et al (2013). Empirical formulae to molecular structures of metal complexes by molar conductance. Synthesis and Reactivity in Inorganic, MetalOrganic and Nano-Metal Chemistry, 43, pp 1162-70.

Ang WH, Casini A, Sava G, Dyson PJ (2011). Organometallic ruthenium-based antitumor compounds with novel modes of action. J Organometallic Chem, 696, 989-98.

Bai L, Fei WD, Gu YY, (2020) Liposomes encapsulated iridium(III) polypyridyl complexes enhance anticancer activity in vitro and in vivo. $J$ Inorganic Biochem, 205, 111014.

Boultif A, Louër D (2004). Powder pattern indexing with the dichotomy method. J Appl Cryst, 37, 724-31.

Chow MJ, Babak MV, Wong DY, et al (2016). Structural Determinants of p53-Independence in Anticancer RutheniumArene Schiff-Base Complexes. Mol Pharm, 13, 2543-54.

Division of Cancer Prevention and Control, Centers for Disease Control and Prevention. (2019). https://www.cdc.gov/cancer/ survivors/patients/side-effects-of-treatment.

Florea AM, Büsselberg D, et al (2011). Cisplatin as an anti-tumor drug: cellular mechanisms of activity, drug resistance and induced side effects. Cancers (Basel), 3, 1351-71.

Freddie B, Isabelle S (2020) WHO report on cancer: setting priorities, investing wisely and providing care for all. Geneva: World Health Organization;. Licence: CC BY-NC-SA 3.0 IGO.

Ganapathy G, Ravindranathan Nair A (2017). Curcuminoids in zingiber zerumbet Rhizomes: Bioguided fractionation and chromatographic Identification of Antimicrobial and Antioxidant Metabolites. J Herbs Spices Med Plants, 23, 169-81.

Hasan K, Bansal AK (2015). Tuning the emission of cationic iridium (III) complexes towards the red through methoxy substitution of the cyclometalating ligand. Sci Rep, 5, 12325.

Kanti Seth S, Mandal S, Purkayastha P, et al (2015). Cyclometalated mono and dinuclear rhodium(III) and iridium(III) complexes with imidazolyl phenanthrolines: Synthesis and photophysical and electrochemical characterization. Polyhedron, 95, 14-23.

Kanti Seth S, Mandal S, Srikanth K, et al (2017). Electronic description of the photophysics of homo and heterodinuclear cyclometallated iridium and rhodium complexes. Eur $J$ Inorg. Chem, 2017, 873-80.

Kavitha P, Rama Chary M, Singavarapu BVVA, et al (2016). Synthesis, characterization, biological activity and DNA cleavage studies of tridentate Schiff bases and their Co(II) complexes. J Saudi Chem Soc, 20, 69-80.

Kumar A, Kumar A, Kumar Gupta R, et al (2016). Cationic $\mathrm{Ru}(\mathrm{II}), \mathrm{Rh}(\mathrm{III})$ and $\mathrm{Ir}(\mathrm{III})$ complexes containing cyclic $\pi$-perimeter and 2-aminophenyl benzimidazole ligands: Synthesis, molecular structure, DNA and protein binding, cytotoxicity and anticancer activity. J Organomet Chem, 801, 68-79.

Lu L, Liu L, Chao W, et al. (2015). Identification of an iridium(III) complex with anti-bacterial and anti-cancer activity. Sci Rep, 5, 1-9.

Mandal S, Poria DK, Seth DK, et al (2014). Cyclometalated rhodium and iridium complexes with imidazole containing 
Schiff bases: Synthesis, structure and cellular imaging. Polyhedron, 73, 12-21.

Mandal S, Poria DK, Ghosh R, et al (2014). Development of a cyclometalated iridium complex with specific intramolecular hydrogen-bonding that acts as a fluorescent marker for the endoplasmic reticulum and causes photoinduced cell death. Dalton Trans, 43, 17463-74.

Morris GM, Huey R, Lindstrom W, et al (2009). AutoDock4 and AutoDockTools4: Automated docking with selective receptor flexibility. J Comput Chem, 30, 2785-91.

Mohammed Shafeeulla R, Krishnamurthy G, Bhojynaik HS, et al (2017). Synthesis of (4-Bromo-3-Fluorophenyl)(Pyrimidin5-yl)Methanol and their Transition Metal Complexes, Spectral, X-ray Powder Diffraction, Cytotoxicity, Molecular Docking, and Biological Evaluation. Indian J Adv Chem Sci, 5, 268-79.

Monneret C (2011) Platinum anticancer drugs. From serendipity to rational design. Ann Pharm Francaises, 69, 286-95.

Mukhopadhyay S, Gupta Rk, Paitandi RP (2015). Synthesis, structure, DNA/protein binding, and anticancer activity of some half-sandwich cyclometalated Rh(III) and Ir(III) complexes. Organometallics, 34, 4491-506.

Ndagi U, Mhlongo N, Soliman ME (2017). Metal complexes in cancer therapy - an update from drug design perspective. Drug Des Devel Ther, 11, 599-616.

Paula M, Marques M, Valero R, et al (2013). Polymorphism in cisplatin anticancer drug. $J$ Phys Chem $B$, 117, 6421-9.

Sinha S, Mandal S, Gupta P (2015). Cyclometalated iridium(III) complexes of (aryl) ethenyl functionalized 2,20-bipyridine: synthesis, photophysical properties and trans-cis isomerization behaviour. RSC Adv, 5, 99529- 39.

Sliwinska-hill U, Pruchnik FP, Latocha M, et al (2013). Properties and biological activity of $[\mathrm{Rh}(\mathrm{COD})(\mathrm{N}-\mathrm{N})]$ BF4 and [ $\mathrm{IrCl} 2(\mathrm{COD})(\mathrm{N}-\mathrm{N})] \mathrm{BF} 4$ polypyridyl complexes, Inorganica Chim. Acta, 400, 26-31.

Soundararajan G, Ramesh Babu NG, Johney J, et al (2017). Extraction of bioactive compounds from rosmarinus officinalis and its anticancer activity against Hela cell line. Int J Sci Res, 6, 165-8.

Sudding LC, Payne R, Govender P, et al (2014). Evaluation of the in vitro anticancer activity of cyclometalated half-sandwich rhodium and iridium complexes coordinated to naphthaldimine-based poly(propyleneimine) dendritic scaffolds. J Organomet Chem, 774, 79-85.

SurendraBabu MS, Umamaheswara Rao B, Krishna V, et al (2017). Synthesis, characterization and DNA cleavage studies of isomeric pyridyl-tetrazole ligands and their $\mathrm{Ni}(\mathrm{II})$ and Zn(II) complexes. J Saudi Chem Soc, 21, 291-9.

Wang L, Zheng K, Li Y, et al (2018). Synthesis, structure and in vitro antiproliferative activities of oxamido-bridged dicopper(II) complexes: A comparative study of experimental evidence and molecular docking of DNA/protein binding. Appl Organometal Chem, 32, 1-16.

Wheate NJ, Walker S, Craig GE, et al (2010). The status of platinum anticancer drugs in the clinic and in clinical trials. Dalton Trans, 39, 8113-27.

Xu Z, Yang Y, Jia X, et al (2020). Novel cyclometalated iridium(III) phosphine-imine $\left(\mathrm{P}^{\wedge} \mathrm{N}\right)$ complexes: highly efficient anticancer and anti-lung metastasis agents in vivo. Inorg Chem Front, 7, 1273-83.

Yang H, Meng G, Zhou Y, et al (2015). The photoluminescent properties of new cationic iridium(III) complexes using different anions and their applications in white light-emitting diodes. Materials (Basel), 8, 6105-16.

Yun C, Boggon TJ, Li Y, et al (2007). Structures of lung cancer-derived EGFR mutants and inhibitor complexes: Mechanism of activation and insights into differential
Evaluation of the Synthesized Novel Iridium (III) Ccomplexes inhibitor sensitivity. Cancer Cell, 11, 217-27.

Yin Zhang K, Liu H W, Him Fong T, et al (2010). Luminescent dendritic cyclometalated iridium(III) polypyridine complexes: Synthesis, emission behavior, and biological properties. Inorg Chem, 49, 5432-43.

Zhou Y, Xie K, Leng R, et al (2017). Highly efficient electrochemiluminescence labels comprising iridium(III) complexes. Dalton Trans, 46, 355-63.

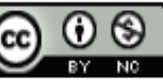

This work is licensed under a Creative Commons AttributionNon Commercial 4.0 International License. 